Jurnal Ilmu Komunikasi UHO : Jurnal Penelitian Kajian Ilmu Komunikasi dan Informasi.

Volume 6, No. 1, Januari 2021, hlm 1-18

\title{
FENOMENA KEBERHASILAN HUBUNGAN ASMARA MELALUI APLIKASI KENCAN ONLINE TINDER: DARI JARI, TURUN KE HATI
}

\author{
Julianti $^{1}$, Rifky Andhika ${ }^{2}$ \\ Program Studi Ilmu Komunikasi, Jurusan Komunikasi Korporat - Paramadina Graduate \\ School of Communication, Universitas Paramadina, Jl. Gatot Subroto Kav. 97, Mampang, \\ Jakarta, Indonesia. \\ Email: julie.ayulestari@yahoo.com / rifkydhikaa@gmail.com
}

\begin{abstract}
ABSTRAK
Penelitian ini dilatarbelakangi oleh adanya pergeseran kebiasaan dan budaya masyarakat Indonesia yang menjadi serba digital seiring dengan adanya perkembangan teknologi yang semakin pesat. Perubahan tersebut menghadirkan adanya budaya baru dalam urusan mencari jodoh. Sejalan dengan tingginya ketertarikan dan minat netizen mencari pasangan di situs online, kini telah hadir berbagai macam aplikasi online yang berfokus pada pencarian pasangan hidup, salah satunya adalah Tinder. Saat ini, Tinder menjadi aplikasi kencan yang banyak disukai oleh netizen. Tidak sedikit masyarakat Indonesia berhasil menemukan pasangan hidupnya melalui Tinder. Penelitian ini membahas tentang bagaimana pola komunikasi serta pengalaman-pengalaman pengguna Tinder dalam menemukan pasangannya di aplikasi ini hingga akhirnya memutuskan untuk menjalin hubungan yang lebih serius. Penelitian ini menggunakan teori interpersonal communication dengan konsep: intimacy, passion dan commitment. Ketiga konsep tersebut kemudian dikonstrukan ke dalam bentuk pertanyaan dalam sebuah wawancara yang akan ditanyakan kepada informan. Peneliti menggunakan metode deskriptif kualitatif dengan tujuan untuk menggambarkan fenomena keberhasilan hubungan asmara melalui aplikasi Tinder disertai dengan informasi yang lebih detail. Temuan yang diperoleh dalam penelitian ini adalah pengguna Tinder berhasil menjalin hubungan yang lebih serius ke jenjang pernikahan setelah melalui proses yang cukup panjang hanya dengan diawali oleh adanya interaksi komunikasi secara bertahap melalui Tinder.
\end{abstract}

Kata-kata Kunci: Kencan Online, Komunikasi Interpersonal, Keintiman, Komitmen, Tinder 
Jurnal Ilmu Komunikasi UHO : Jurnal Penelitian Kajian Ilmu Komunikasi dan Informasi.

Volume 6, No. 1, Januari 2021, hlm 1-18

\title{
THE SUCCESSFUL PHENOMENON OF THE ROMANCE RELATIONSHIP THROUGH THE TINDER APPLICATION: FROM FINGERS DOWN TO HEART
}

\begin{abstract}
This research was motivated by a shift in the habits and culture of Indonesian society which became completely digital in line with the increasingly rapid development of technology. These changes present a new culture of finding a mate. In line with the high interest of netizens looking for partners through online sites, there are various online applications that focus on finding a partner, such as Tinder. Currently, Tinder is one of favorite dating application by netizens. Many people have managed to find life partner through Tinder. This research discusses how the communication patterns and experiences of Tinder users in finding their partners until they finally decide to have a serious relationship. This study uses interpersonal communication theory with the concepts: intimacy, passion, commitment. The third concept is constructed into the form of interview questions that will be asked to informants. Researchers used a qualitative descriptive method in order to describe the phenomenon that describes the relationship as through the Tinder application with more detailed information. The findings obtained in this study are Tinder users have succeeded in establishing a serious relationship to the level of marriage after going through a long process only initiated by gradual communication interactions through Tinder.
\end{abstract}

Keywords: Online Dating, Interpersonal Communication, Intimacy, Commitment, Tinder. 
Jurnal Ilmu Komunikasi UHO : Jurnal Penelitian Kajian Ilmu Komunikasi dan Informasi.

Volume 6, No. 1, Januari 2021, hlm 1-18

\section{PENDAHULUAN}

Hadirnya perkembangan teknologi yang semakin canggih telah membawa perubahan yang sangat signifikan terhadap pola interaksi masyarakat. Hampir semua hal dapat dilakukan secara daring, mulai dari bermain game, berbelanja, belajar, diskusi dan beberapa kegiatan lainnya. Hal ini telah membuat fungsi internet kian meluas dan banyak menghadirkan fiturfitur baru dalam menjawab kebutuhan masyarakat, salah satunya hadirnya aplikasi pencari jodoh. Aplikasi kencan online pertama kali dibuat untuk mencari relasi pertemanan. Namun, seiring berjalannya waktu, banyak orang yang menggunakan aplikasi tersebut sebagai media pencari jodoh.

Tidak dapat dipungkiri, kompleksitas peran dan tuntutan karir dalam pekerjaan telah membuat sebagian besar masyarakat terjebak dalam rutinitas yang sama, sehingga menghambat mereka untuk berkenalan dan bertemu dengan orang baru yang menjadi potensial pasangan mereka. Oleh karena itu, menjamurnya aplikasi kencan online sangat disambut baik oleh sebagian besar masyarakat Indonesia, khususnya bagi mereka yang tinggal di perkotaan.

Berdasarkan hasil survei Asosiasi Penyelenggara Jaringan Internet Indonesia (APJI) tahun 2019, jumlah pengguna internet di Indonesia tercatat mengalami peningkatan sebesar $10,12 \%$ dibandingkan dengan tahun lalu. Dalam hal ini, ada sebanyak 171,17 juta jiwa atau sekitar 64,8\% penduduk Indonesia sudah terhubung ke internet (Pratomo, 2019). Berdasarkan data tersebut, dapat dipahami bahwa penetrasi internet di Indonesia mengalami peningkatan yang signifikan setiap tahunnya. Hal ini juga berarti bahwa sebagian besar penduduk Indonesia sudah sangat melek teknologi dan terbiasa menggunakan internet dalam kehidupan sehari-hari.

Saat ini, teknologi internet sudah berkembang sedemikian pesat. Ada banyak fitur maupun aplikasi yang dapat diunduh secara gratis hanya dengan terhubung ke internet. Mulai dari aplikasi musik, game, olah raga, berita online hingga aplikasi- aplikasi yang bersifat personal seperti aplikasi kencan berbasis online. Hadirnya aplikasi-aplikasi tersebut seakan menjadi daya pikat yang sulit diabaikan para penggunanya. Bagaimana tidak, kini hampir semua hal dapat diakses hanya dengan melalui telepon genggam. Hadirnya teknologi internet telah mengubah gaya hidup dan pola pikir sebagian besar masyarakat Indonesia, bahkan dunia. 
Jurnal Ilmu Komunikasi UHO : Jurnal Penelitian Kajian Ilmu Komunikasi dan Informasi.

Volume 6, No. 1, Januari 2021, hlm 1-18

Daftar aplikasi online yang paling sering digunakan sepanjang tahun 2010-2019 diantaranya: Netflix, Tinder, Pandora music, Tencent Video, LINE dan lain sebagainya seperti yang tercantum pada gambar di bawah ini (Prihastomo, 2019):

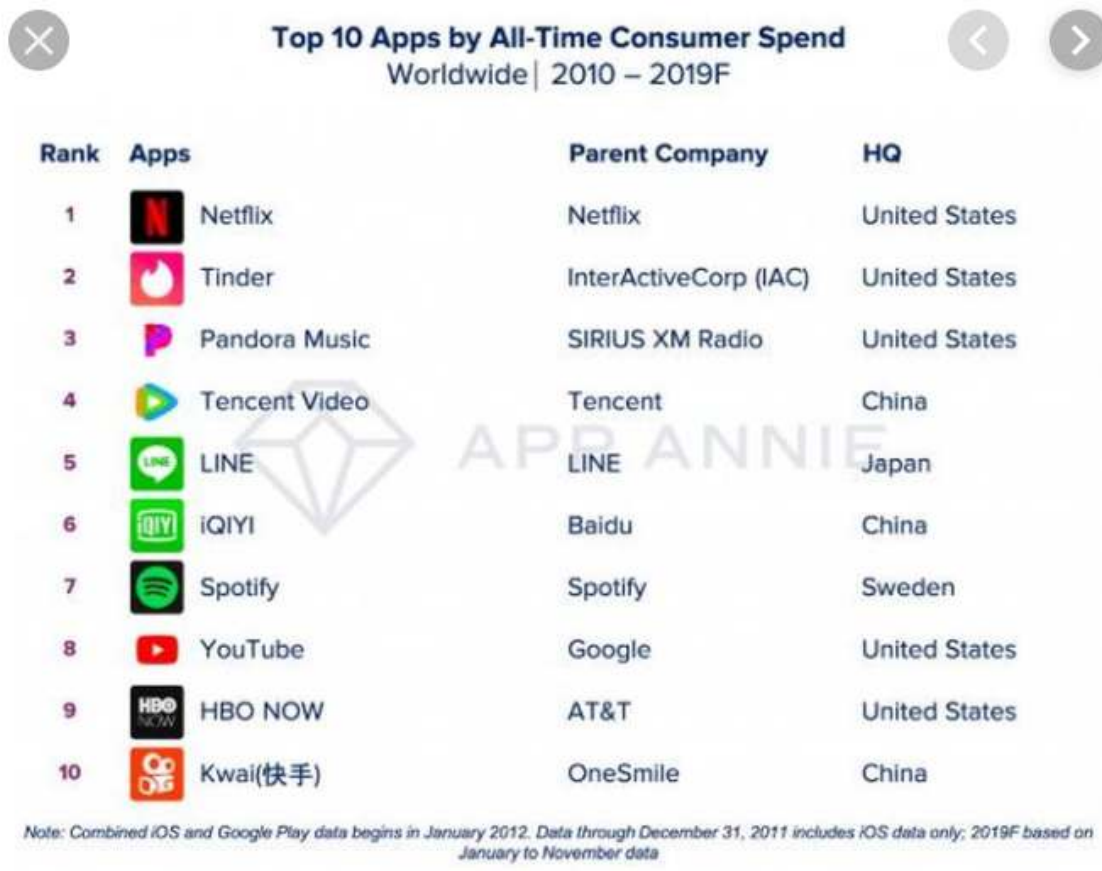

Sumber: Grid.id

\section{Gambar 1 Grafik 10 Aplikasi Paling Sering Digunakan 2010-2019}

Berdasarkan gambar di atas, dapat dipahami bahwa penduduk Indonesia lebih banyak menggunakan internet untuk mengakses aplikasi video, seperti Netflix. Dalam hal ini, Netflix menempati posisi nomor satu dan menjadi aplikasi yang paling sering dikunjungi selama 10 tahun terakhir. Kemudian, aplikasi selanjutnya yang banyak dikunjungi oleh netizen adalah aplikasi kencan berbasis online, yaitu Tinder.

Tinder adalah aplikasi kencan berbasis online yang memfasilitasi komunikasi antara pengguna yang saling tertarik satu sama lain. Melalui aplikasi tersebut, seseorang bisa dengan mudah berinteraksi dan mengobrol secara pribadi dengan pria/wanita yang disukainya. Berbeda dengan aplikasi online dating lainnya, Tinder memiliki fitur yang terbilang lebih sederhana. Cara log in nya pun terbilang sangat mudah. Seorang user hanya perlu membuka aplikasi Tinder dan menghubungkannya dengan akun Facebook atau melalui verifikasi SMS. Kemudian, Ia akan diarahkan ke halaman utama berisikan pilihan foto profil pengguna Tinder lainnya. Pada halaman tersebut, seseorang dapat memilih siapa saja yang akan dijadikan teman kencan nya. Untuk metode pemilihannya pun terbilang sangat mudah. 
Jurnal Ilmu Komunikasi UHO : Jurnal Penelitian Kajian Ilmu Komunikasi dan Informasi.

Volume 6, No. 1, Januari 2021, hlm 1-18

Seorang pengguna hanya perlu menggeser ke kanan (swipe right) apabila menyukai profil yang ditampilkan, dan menggeser ke kiri (swipe left) apabila tidak menyukainya.

Dalam aplikasi ini, daftar profil yang telah dipilih sebagai teman dapat masuk ke dalam friend list si pengguna apabila keduanya saling mengger ke kanan (swipe right). Tinder akan mengirimkan pemberitaan berupa ucapan selamat kepada penggunanya apabila telah memilih pasangannya satu sama lain (swipe right). Setelah itu, para pengguna Tinder dapat mengirimkan pesan atau chat di laman Tinder nya masing-masing. Aplikasi ini terbilang sangat mudah dan efisien bagi mereka yang tidak memiliki banyak waktu, namun memiliki keinginan untuk mencari pasangan.

Dikutip dari medcom.id, Tinder didirikan pada tahun 2012 oleh Sean Rad dan Justin Mateen, yang bertemu di University of Southern California. Tinder sendiri didanai dan dikembangkan di dalam InterActiveCorp (IAC), inkubator startup yang dijalankan oleh perusahaan induk Tinder, Match Group. Dilihat dari laman TechCrunch, aplikasi ini telah memenangkan Penghargaan TechCrunch's untuk kategori "Teknologi baru terbaik tahun 2013”. Pada kuarter ketiga 2019, Tinder telah memiliki kurang lebih 5,7 juta subscribers dan telah di download sebanyak 340 juta kali di Android dan iOS. Per Januari 2018, telah terjadi 1,6 Triliun swipe setiap hari pada aplikasi Tinder (wpmultiverse.org).

Berdasarkan penjelasan tersebut, dapat dipahami bahwa Tinder merupakan aplikasi online dating yang paling banyak dipilih oleh para pengguna internet saat ini. Hal inilah yang membuat Tinder berhasil menduduki posisi kedua selama 10 tahun terakhir setelah Netflix.

Saat ini, terdapat banyak pilihan aplikasi kencan berbasis online yang tersedia di internet, diantaranya: Tantan, OkCupid, BeeTalk, Match, Badoo dan lain sebagainya. Namun, Tinder menjadi aplikasi kencan online yang paling banyak digunakan oleh masyarakat Indonesia. Sebesar 5,2 juta pengguna Tinder rela menjadi pengguna premium Tinder dengan membayar biaya tambahan pada aplikasi kencan online ini (CNN Indonesia, 2019).

Sementara itu, Jika kita lihat di Play Store per tanggal 27 Desember 2019 Pukul 17.49 WIB, aplikasi Tinder sudah diunduh lebih dari 100 juta kali di seluruh dunia dan diulas lebih dari 3,6 Juta pengguna, dengan sebagian besar memberikan bintang 5 atau bisa dikatakan sangat puas dengan aplikasi tersebut. Banyak pengguna Tinder yang menggunakan aplikasi tersebut hanya untuk iseng semata bahkan hanya untuk One Night Stand saja (Kumparan, 2019). 
Jurnal Ilmu Komunikasi UHO : Jurnal Penelitian Kajian Ilmu Komunikasi dan Informasi.

Volume 6, No. 1, Januari 2021, hlm 1-18

Berdasarkan data di atas, dapat dipahami bahwa masyarakat Indonesia sangat menyukai kencan berbasis online. Hal ini sekaligus telah membuka pandangan kita bahwa kehadiran teknologi internet telah menggeser kebiasaan masyarat Indonesia.

Pada jaman dulu, pencarian jodoh dilakukan secara konvensional yaitu bertemu secara tatap muka. Salah satu lawan jenis tertarik atau keduanya saling tertarik satu sama lain melakukan pendekatan dan mengenal satu sama lain melalui status pacaran, kemudian berakhir ke jenjang yang lebih serius yaitu pernikahan. Dengan adanya perubahan budaya di masyarakat saat ini, proses pencarian jodoh memiliki alternatif yang lain yaitu melalui aplikasi pencarian jodoh secara online. Jika dulu masyarakat kita terbiasa mencari jodoh melalui biro jodoh koran, kini hal tersebut dapat dilakukan dengan mudah hanya dengan menggunakan gadget pribadinya. Dengan internet, komunikasi interpersonal dapat dilakukan dengan cepat dan mudah hanya dengan mengirimkan chat melalui WhatsApp, LINE, Skype atau aplikasi online dating seperti Tinder. Namun, apakah konsep kencan berbasis online ini terbilang lebih sukses dibanding dengan kencan secara langsung?

Menurut Julia T. Wood, 2015, dalam bukunya berjudul Interpersonal Communication mengatakan bahwa, "hubungan yang sukses dijalin dengan adanya komitmen antara individu unik yang menganggap mereka akan menjadi individu yang bahagia satu sama lain dan berkelanjutan dari kehidupan masing-masing". Berdasarkan penjelasan tersebut, dapat dipahami bahwa suatu hubungan dapat dikatakan berhasil apabila keduanya memiliki komitmen untuk terus bersama dan hidup bahagia.

Selain itu, dalam buku yang sama, Wood juga mengatakan, "suatu hubungan romantis dan berkomitmen dapat tercipta karena adanya tiga dimensi, meliputi: intimacy, commitment dan passion. Passion diartikan sebagai sebuah perasaan yang sangat positif dan keinginan kuat untuk orang lain. Namun, perasaan tersebut tidak hanya terbatas kepada seksual dan sensual saja. Selanjutnya komitmen merupakan sebuah niat untuk tetap menjalin hubungan yang telah dibangun sejak awal. Terakhir adalah intimacy yang merujuk pada proses interaksi dimana partner sosial dari seseorang merupakan hasil dari berbagi pikiran dan perasaan pribadi sehingga keduanya menjadi merasa dipahami, dihargai dan diperhatikan satu sama lain”. Berdasarkan penjelasan tersebut, dapat dipahami bahwa indikator dalam hubungan yang sukses terdiri dari tiga hal, yaitu: adanya keintiman dalam sebuah hubungan, memiliki passion yang tinggi satu sama lain, serta mampu berkomitmen untuk terus menjaga hubungan yang telah dibangun. Jika dikaitkan dengan fenomena online dating yang tengah marak saat 
Jurnal Ilmu Komunikasi UHO : Jurnal Penelitian Kajian Ilmu Komunikasi dan Informasi.

Volume 6, No. 1, Januari 2021, hlm 1-18

ini, aplikasi Tinder dapat dijadikan sebagai salah satu tool/alat untuk mencari partner dalam membangun sebuah hubungan yang berhasil.

Sejak manusia diciptakan di Bumi, Tuhan telah menciptakan manusia secara berpasangan, selayaknya Adam dan Hawa. Oleh karena itu, manusia membutuhkan hubungan antar lawan jenis untuk menyempurnakan kehidupan mereka dan melanjutkan keturunan. Proses tersebut membutuhkan interaksi sosial, salah satunya dengan mencari jodoh.

Saat ini, tidak sedikit dari pengguna Tinder yang berhasil menjalin hubungan ke jenjang yang lebih serius seperti jenjang pernikahan. Salah satu contohnya adalah Mutia (nama samaran), seorang karyawati swasta di bilangan Duren Tiga, Jakarta Selatan. Walaupun pada awalnya dia hanya iseng saja menggunakan Tinder, namun karena komunikasi yang berhasil di antara kedua belah pihak, hubungan keduanya pun semakin serius hingga memutuskan untuk segera melangsungkan pernikahan.

Tidak hanya itu, berbagai penelitian mengenai aplikasi Tinder juga sudah banyak dilakukan, salah satunya adalah penelitian yang dilakukan oleh Merry Fridha dan Meria Octavianti (2016). Dalam hal ini, mereka menyimpulkan bahwa saat ini ini kencan yang dilakukan oleh kaum millennial tidak membutuhkan proses yang panjang. Jika sudah merasa cocok, maka akan berlanjut untuk bersenang-senang. Hal ini karena sebagian besar pengguna aplikasi kencan online, khususnya Tinder menggunakan aplikasi tersebut dengan tujuan hiburan semata dan untuk hubungan secara singkat saja atau lebih populer dengan sebutan One Night Stand.

Namun, hal tersebut bisa jadi hanya sebatas stereotype dibeberapa kalangan masyarakat saja. Berdasarkan jurnal penelitian lainnya yang dilakukan oleh Gordon P.D, M. Isabela, Nathalia, Maria Jose dan Antonio yang berjudul Looking for the right swipe: Gender Differences in Self-Presentation on Tinder Profiles, disebutkan bahwa cinta satu malam atau One Night Stand hanya salah satu alasan pengguna Tinder memakai aplikasi tersebut. Sebagian besar pengguna menggunakan aplikasi tersebut dengan tujuan untuk mencari hubungan yang baik atau mencari cinta. Berdasarkan jurnal tersebut, ada sekitar 46\% pengguna yang match lewat aplikasi tersebut, dan hanya 19\% saja yang melanjutkan hubungan cinta satu malam saja. Hal ini membuktikan bahwa lebih banyak yang mencari hubungan serius lewat aplikasi tersebut. Melihat adanya fenomena tersebut, jurnal ini akan membahas tentang keberhasilan hubungan asmara melalui aplikasi kencan berbasis online yaitu Tinder. 
Jurnal Ilmu Komunikasi UHO : Jurnal Penelitian Kajian Ilmu Komunikasi dan Informasi.

Volume 6, No. 1, Januari 2021, hlm 1-18

Berdasarkan paparan di atas, jurnal ini bertujuan untuk memberikan gambaran atas fenomena interaksi komunikasi yang terjadi dalam aplikasi pencari jodoh Tinder, sehingga diharapkan mampu memberikan input dan gambaran secara menyeluruh bagi calon pengguna Tinder maupun masyarakat luas tentang aplikasi Tinder dan kegunaannya.

Selain itu, jurnal ini bertujuan untuk membuktikan keberhasilan komunikasi interpersonal yang terjalin secara online melalui aplikasi pencari jodoh Tinder. Peneliti ingin mengamati apakah komunikasi interpersonal dapat tetap terjalin tanpa hambatan dan gangguan walaupun dilakukan secara daring. Hasil jurnal ini dapat menjawab pertanyaan peneliti tentang hal tersebut, sekaligus dapat memberikan gambaran bagi calon pengguna Tinder maupun masyarakat luas.

\section{Komunikasi di Era Digital \& Perubahan Budaya}

Menurut Manuel Castells, 2009, dalam bukunya berjudul "Communication in the Digital Age", komunikasi adalah berbagi makna melalui pertukaran informasi. Proses komunikasi ditentukan oleh teknologi komunikasi, karakteristik pengirim dan penerima informasi, kode referensi budaya dan protokol komunikasi, serta ruang lingkup proses komunikasi”. Berdasarkan uraian tersebut, dapat dipahami bahwa komunikasi sudah banyak mengalami perubahan yang menjadi serba digital. Salah satu penyebabnya adalah transformasi teknologi yang didasarkan pada digitalisasi komunikasi, jaringan komputer, perangkat lunak canggih, difusi peningkatan kapasitas transmisi broadband, dan komunikasi lokal / global di mana-mana melalui jaringan nirkabel dengan akses Internet.

Sebelum era digital, manusia melakukan komunikasi secara langsung secara tatap muka melalui telepon ataupun surat menyurat. Kemudian terjadi perubahan budaya dalam berkomunikasi, di mana masyarakat melakukan proses komunikasi atau interaksi sosial melalui platform-platform digital yang telah tersedia di gadget atau komputer mereka. Salah satu komunikasi dan interaksi sosial yang berubah adalah ketika mencari jodoh atau teman kencan. Berkaitan dengan penggunaan aplikasi pencari jodoh tersebut, saat ini masyarakat sudah banyak menggunakan aplikasi kencan berbasis online, salah satunya melalui Tinder.

\section{Kebutuhan Inklusi}

William C. Schutz, dalam bukunya yang berjudul "FIRO. A Three-Dimensional Theory of Interpersonal Behavior", mengungkapkan bahwa pada teori Fundamental Interpersonal Relationship Orientation terdapat tiga kebutuhan manusia salah satunya adalah 
Jurnal Ilmu Komunikasi UHO : Jurnal Penelitian Kajian Ilmu Komunikasi dan Informasi.

Volume 6, No. 1, Januari 2021, hlm 1-18

kebutuhan inklusi. Fenomena media sosial dan aplikasi-aplikasi chatting dan dating yang sangat booming di kalangan Millenial sangat erat kaitannya dengan kebutuhan inklusi, di mana kebutuhan manusia adalah untuk diketahui serta dikenal dalam sebuah interaksi antar manusia sebagai partisipan. Banyak kaum Millenial yang berbondong-bondong membuat berbagai macam akun media sosial dan aplikasi-aplikasi chatting dan dating agar bisa berinteraksi dengan kerabatnya ataupun dengan orang yang belum mereka kenal. Hal ini dilakukan agar mereka mendapatkan pengakuan secara sosial di dalam masyarakat.

\section{Teori Penetrasi Sosial}

Jika seseorang menyebut kata Tinder pasti sebagian besar kaum Millenial sudah pasti mengetahui apa itu Tinder. Tinder merupakan sebuah platform pencari "jodoh" yang sangat disukai oleh pengguna aplikasi kencan baru-baru ini. Dalam hal ini, penggunaan Tinder di kalangan Millenial bisa kita kaitkan dengan salah satu perspektif komunikasi interpersonal yaitu teori penetrasi sosial.

Dalam buku karya Griffin yang berjudul A First Look at Communication Theory (114-115), dijelaskan bahwa teori ini dikenal dengan analogi kulit bawang, yaitu manusia memiliki lapisan-lapisan yang bisa kita kupas lapisan demi lapisan. Analogi ini diibaratkan terdapat empat lapisan. Semakin kita mengupas ke dalam, maka kita akan tahu apa isi terdalam dari bagian bawang itu sendiri. Sama halnya dengan penggunaan aplikasi Tinder untuk mencari "jodoh". Pada pembuatan profil, dalam hal ini merupakan lapisan yang pertama, seorang pengguna Tinder cenderung memberikan informasi yang tidak terlalu banyak. Ketika seseorang swipe kanan atau super like dan match, maka akan berlanjut ke perkenalan di direct message, dan ini sudah masuk ke lapisan ke dua. Pada tahap selanjutnya, yaitu tahap ketiga, dua orang yang saling match ini akan saling bercerita tentang diri mereka jauh lebih dalam untuk bisa saling mengenal satu sama lain. Pada tahap akhir atau tahap ke empat ketika sudah tercipta suatu kenyamanan atau hubungan yang lebih serius, maka kedua belah pihak sudah saling mengetahui satu sama lain dan komunikasi yang terjalin sudah sangat intim.

\section{Teori Keterbukaan Diri}

Dikutip dari Jurnal yang berjudul Self-Disclosure: Theories and Model Review, Mohan Masaviru, teori ini merupakan suatu teori yang menjelaskan mengenai tindakan mengungkapkan informasi pribadi tentang diri kita yang tidak mungkin ditemukan oleh orang 
Jurnal Ilmu Komunikasi UHO : Jurnal Penelitian Kajian Ilmu Komunikasi dan Informasi.

Volume 6, No. 1, Januari 2021, hlm 1-18

lain dengan cara yang lain. Informasi ini berkaitan dengan topik-topik yang bahkan seseorang tidak berpikiran untuk membahas hal tersebut dengan orang-orang tertentu, oleh karena itu kita menyimpannya dalam diri kita sendiri (Derlega, Winstead, \& Greene, 2001; Steinberg, 2007; Tang et al., 2013; Wood, 2010). Ketika kita match di Tinder dengan seseorang, kita memutuskan apakah kita akan membuka diri terhadap lawan bicara kita di Tinder atau tidak. Dengan keputusan kita untuk membuka diri dengan lawan bicara tersebut, berarti kita setuju untuk melanjutkan hubungan ke tingkat selanjutnya dengan lawan bicara tersebut.

Berdasarkan kajian pustaka yang telah dijelaskan di atas, maka penulis ingin membahas mengenai tingkat keberhasilan seseorang dalam berkomunikasi di aplikasi Tinder ke jenjang yang lebih serius.

\section{METODE PENELITIAN}

Jenis metode penelitian yang digunakan dalam penelitian ini adalah metode deskriptif kualitatif. Metode ini digunakan untuk menggambarkan suatu kejadian atau peristiwa dari objek penelitian yang hendak diteliti. Dikutip dari jurnal milik Mohammad Mulyadi yang berjudul penelitian kuantitatif dan kualitatif serta pemikiran dasar Menggabungkannya, pendekatan kualitatif menekankan pada makna dan pemahaman dari dalam (verstehen), penalaran, definisi yang dihubungkan dengan situasi tertentu maupun dalam konteks tertentu, dimana titik penekanan pada penelitian lebih difokuskan untuk meneliti hal-hal terkait dengan kehidupan sehari-hari. Proses merupakan hal yang penting dalam pendekatan kualitatif dibandingan dengan hasil akhir; kondisi serta kuantitas dari gejala-gejala yang diketahui menjadi faktor utama yang membuat urutan-urutan kegiatan dapat berubah-ubah. Dalam hal ini, peneliti tertarik menggunakan metode deskriptif kualitatif karena ingin menggambarkan tentang fenomena keberhasilan suatu hubungan asmara melalui aplikasi kencan online Tinder.

\section{HASIL DAN PEMBAHASAN}

Sebelum membahas lebih dalam tentang hasil penelitian, peneliti akan membahas tentang subjek yang dipakai dalam penelitian ini. Dalam hal ini, subjek penelitiannya adalah seorang karyawan swasta yang dapat dikatakan berhasil dalam menjalin hubungan asmara melalui aplikasi Tinder. Untuk melengkapi penelitian, informan dalam penelitian ini diwawancara terkait pandangan dan pengalamannya dalam menggunakan aplikasi Tinder serta keputusannya melanjutkan hubungan lebih serius ke jenjang pernikahan. Dalam hal ini, 
Jurnal Ilmu Komunikasi UHO : Jurnal Penelitian Kajian Ilmu Komunikasi dan Informasi.

Volume 6, No. 1, Januari 2021, hlm 1-18

indikator keberhasilan dalam sebuah hubungan, tidak selalu berakhir dalam status pernikahan. Hal ini karena tidak sedikit dari kita yang menganggap bahwa pernikahan bukanlah status wajib yang harus dilalui bagi pasangan yang berbahagia. Hubungan yang berhasil bisa saja terjadi tanpa adanya pernikahan. Hal tersebut bergantung pada pandangan dan ideologi masing-masing informan. Namun, pada penelitian ini, informan memilih untuk melanjutkan hubungannya ke jenjang pernikahan.

Pada tahap awal, seorang karyawan swasta yang menjadi objek dalam penelitian ini mengetahui informasi tentang Tinder dari beberapa teman yang telah lebih dulu menggunakan aplikasi tersebut. Berdasarkan cerita dan pengalaman dari relasinya, informan tertarik untuk menggunakan aplikasi Tinder dan mulai berkenalan dengan beberapa pria yang disukainya. Interaksi yang terjalin pada perkenalan pertama terbilang cukup standar, yakni sebatas perkenalan, menanyakan kabar, hobi, pekerjaan, usia dan ekspektasi menggunakan aplikasi tersebut. Seiring perjalananannya, informan telah melakukan interpersonal communication dengan 4 orang pria yang dianggapnya cocok. Komunikasi pun terjalin tidak hanya melalui aplikasi Tinder, tetapi juga mulai beralih ke WhatsApp dan LINE.

Jika pada perkenalan pertama, informan hanya melakukan komunikasi standar dan tanpa adanya unsur intimacy, pada tahap selanjutnya informan mengaku telah banyak berdiskusi dan menjadikan partner yang ditemuinya di Tinder selayaknya teman. Sehingga, tidak jarang informan bertukar pikiran dan akhirnya tertarik untuk melakukan komunikasi secara tatap muka. Selama kurang lebih 3 bulan menjalin komunikasi secara online, informan memutuskan untuk bertemu dengan keempat teman pria nya dalam waktu yang berbeda. Informan mengaku sangat selektif dan mengamati secara detil tentang kualitas personal dan efektivitas komunikasi yang terjalin, hingga akhirnya informan memutuskan untuk lebih mendalami hubungan dengan salah satu teman pria yang disukainya.

Seiring perjalanannya, informan mengaku menunjukan ketertarikan yang cukup besar pada pria yang dikenalnya tersebut, namun karena tuntutan pekerjaan yang cukup tinggi diantara keduanya, komunikasi pun sempat terhenti selama beberapa tahun. Informan bahkan mengaku telah menjalin hubungan dengan pria lain dan melupakan pria yang dikenalnya di Tinder. Namun setelah hubungan tersebut putus, pria yang dikenalnya di Tinder itu tiba-tiba hadir kembali, menanyakan kabar via social media Instagram dan komunikasi pun terjalin lebih intens dari sebelumnya.

Dalam penelitian ini, peneliti akan membahas tentang keberhasilan hubungan asmara informan yang didasarkan tiga dimensi, yaitu: intimacy, passion dan commitment. Pada 
Jurnal Ilmu Komunikasi UHO : Jurnal Penelitian Kajian Ilmu Komunikasi dan Informasi.

Volume 6, No. 1, Januari 2021, hlm 1-18

dimensi intimacy, informan mengaku memiliki hubungan yang intim setelah melalui proses interaksi yang panjang selama kurang lebih satu tahun. Berikut hasil wawancaranya:

"Saya mengenal pasangan saya selama tiga tahun terakhir, namun kami berdua tidak melakukan komunikasi yang intens sehingga kami sempat terputus dan hilang kontak selama hampir dua tahun lamanya. Namun, setelah itu pasangan saya kembali menghubungi saya melalui aplikasi Tinder dan komunikasi pun mengalir begitu saja. Awalnya saya hanya berencana untuk berteman saja dengannya, namun karena adanya komunikasi yang intens, kami pun akhirnya memutuskan untuk menjalin hubungan dalam ikatan pacaran. Komunikasi yang intens terjalin perlahan selama kurang lebih satu tahun lamanya. Butuh waktu bagi kami berdua untuk mengenal satu sama lain dan akhirnya memutuskan untuk melangsungkan pernikahan".

(hasil wawancara dengan seorang informan pengguna aplikasi Tinder bernama Mutia pada Sabtu, 18 Januari 2020 pukul 12:31 WIB).

Berdasarkan hasil wawancara tersebut, dapat dipahami bahwa informan telah melewati proses yang cukup panjang hingga akhirnya merasa yakin dengan keputusannya untuk menikahi seorang pria yang dikenalnya melalui aplikasi Tinder. Pada dimensi intimacy, informan mengaku lebih banyak menghabiskan quality time dengan menyaksikan film bioskop setiap minggu, menemani pasangannya berbelanja dan berkunjung ke rumahnya. Rutinitas ini terjalin dengan cukup intens hingga menimbulkan ikatan yang erat diantara keduanya. Tidak hanya itu, pihak orang tua mereka pun seolah memberikan lampu hijau bagi keduanya dan meminta mereka untuk segera melangsungkan pernikahan. Adanya dukungan yang penuh dari keluarga inti membuat informan semakin yakin untuk meneruskan hubungan ke jenjang yang lebih serius, yakni pernikahan.

"Saya dan pasangan saya selalu menghabiskan waktu bersama di bioskop, restaurant, mall dan di rumah keluarga. Hal ini kami lakukan untuk semakin mendekatkan diri dan mengenal pasangan denagn lebih baik. Selama hampir dua tahun lamanya, hubungan kami terbilang semakin dekat hingga kami tidak malu lagi melakukan hal yang memalukan seperti kentut atau bersendawa".

(hasil wawancara dengan seorang informan pengguna aplikasi Tinder bernama Mutia pada Sabtu, 18 Januari 2020 pukul 12:31 WIB).

Berdasarkan hasil wawancara di atas, dapat dipahami bahwa informan mengaku lebih intim dengan pasangannya setelah banyak menghabiskan waktu bersama dan tidak segan lagi melakukan apapun di depan pasangannya, termasuk hal yang memalukan sekalipun. Hal ini juga menunjukan bahwa intensitas interaksi dan lamanya hubungan informan dengan pasangannya menjadi faktor yang sangat besar dalam menguatkan hubungan keduanya. 
Jurnal Ilmu Komunikasi UHO : Jurnal Penelitian Kajian Ilmu Komunikasi dan Informasi.

Volume 6, No. 1, Januari 2021, hlm 1-18

Dimensi kedua adalah passion yang diartikan sebagai suatu perasaan yang sangat positif dan kuat terhadap pasangan. Pada dimensi ini, informan mengaku memiliki ketertarikan dan keinginan yang sangat kuat untuk membahagiakan pasangannya. Bahkan, ia berkata tidak keberatan untuk melakukan pengorbanan demi kebahagiaan pasangannya. Menurut peneliti, hal ini menjadi kunci sukses dalam penentu keberhasilan hubungan informan. Ini karena setiap orang menyukai perhatian yang ditunjukan oleh pasangannya, apalagi melalui sebuah pengorbanan. Pengorbanan menjadi pencapaian yang sangat besar dalam sebuah hubungan. Melengkapi penelitian ini, berikut adalah hasil wawancara dengan informan:

\footnotetext{
"Bagi saya, tidak ada hubungan yang indah tanpa adanya pengorbanan dan loyalitas. Rasa sayang dan cinta saya kepada pasangan saya tunjukan dengan perhatianperhatian kecil yang saya tunjukan setiap harinya, disertai dengan pengorbanan yang berarti untuk masa depan hubungan kami”

(Hasil wawancara dengan seorang informan pengguna aplikasi Tinder bernama Mutia pada Sabtu, 18 Januari 2020 pukul 12:31 WIB).
}

Berdasarkan uraian di atas, peneliti menyimpulkan bahwa terdapat ikatan emosi yang sangat erat antara informan dengan pasangannya. Hal tersebut terlihat dari ekspresi dan gaya bicara informan pada saat diwawancarai. Ia terlihat seperti sangat emosional dengan mata yang berbinar saat mengatakan tentang pengorbanan yang dilakukannya untuk hubungan asmaranya.

Dimensi yang ketiga adalah commitment. Commitment adalah sebuah sikap yang diambil dan diputuskan untuk terus menjalani hubungan sampai kapanpun. Kata komitmen di setiap negara seringkali memiliki arti yang berbeda. Di Indonesia, seseorang dikatakan berkomitmen terhadap hubungannya apabila berani melangkah ke jenjang yang lebih serius, yaitu pernikahan. Hal ini bisa saja berbeda dengan negara lainnya, karena setiap negara memiliki norma dan budaya yang berbeda.

Berdasarkan jawaban dan keputusan yang diambil oleh informan, peneliti dapat menyimpulkan bahwa informan menganut budaya ketimuran yang menilai bahwa bukti komitmennya pada pasangan harus ditunjukkan melalui ikatan pernikahan. Setelah menjalin hubungan selama hampir dua tahun lamanya, informan merasa sudah tiba saatnya untuk menunjukan komitmennya terhadap pasangan dan hubungan asmaranya. Tinder dianggap sebagai aplikasi yang sangat mempermudah informan dalam mencari dan memilih pasangan di tengah sibuknya rutinitas sehari-hari. 
Jurnal Ilmu Komunikasi UHO : Jurnal Penelitian Kajian Ilmu Komunikasi dan Informasi.

Volume 6, No. 1, Januari 2021, hlm 1-18

"Saya merasa sangat bahagia dan bangga pada diri saya sendiri karena saya telah berhasil menata masa depan saya tahap demi tahap. Memiliki pekerjaan dengan tanggungjawab yang cukup tidak mudah bagi saya. Di samping itu, saya juga harus membagi waktu dengan pendidikan, keluarga, dan bisnis yang saya jalani. Padatnya rutinitas membuat saya seakan jauh dari kehidupan sosial dan pertemanan secara tatap muka. Namun, Tinder memberikan cara yang baru dalam menjalin hubungan. Saya tidak menyangka bahkan saya akan segera menikahi seorang laki-laki yang saya temuka dalam aplikasi pencarian jodoh secara online"

(Hasil wawancara dengan seorang informan pengguna aplikasi Tinder bernama Mutia pada Minggu, 19 Januari 2020 pukul 10:22 WIB).

Berdasarkan penjelasan di atas, dapat dipahami bahwa informan merasa sangat beruntung telah diberikan kemudahan dalam mencapai salah satu mimpinya dalam situs pencarian jodoh berbasis online. Pada saat wawancara dilakukan, informan terlihat tersenyum manis dengan pipi yang merona. Ekspresi yang ditunjukan sangatlah positif dan terlihat sangat bangga menceritakan pengalamannya menemukan pasangannya di situs aplikasi online.

Setelah hampir dua tahun menjalin hubungan dengan laki-laki yang dikenalnya melalui Tinder, informan mengaku telah $80 \%$ menyiapkan rencana pernikahannya. Semua persiapan telah hampir selesai dan hanya tinggal menunggu beberapa bulan lagi, informan akan segera melangsungkan pernikahan dengan pasangannya.

Jika dikaitkan dengan teori Interpersonal Communication menurut Wood, informan dalam penelitian ini telah berhasil menjalin hubungan dengan pasangannya. Indikator tersebut terlihat dari adanya ikatan hubungan yang sangat erat berdasarkan konsep intimacy, adanya rasa aman dan kebahagiaan dalam hubungannya dengan pasangan, serta niat untuk segera melangsungkan pernikahan sebagai bukti komitmen yang kuat diantara keduanya.

\section{KESIMPULAN}

Berdasarkan hasil temuan yang diperoleh, dapat disimpulkan bahwa hadirnya aplikasi Tinder telah mengubah cara netizen menemukan tambatan hati secara online. Keberhasilan hubungan yang diperoleh oleh informan dalam penelitian ini telah membuktikan bahwa kunci sukses untuk menjalin sebuah hubungan berawal dari adanya komunikasi yang intens disertai dengan adanya kecocokan satu sama lain.

Komunikasi menjadi bagian yang sangat penting dalam kehidupan manusia. Walaupun kini internet telah memberikan kemudahan dalam berkomunikasi dan menemukan teman dan pasangan secara online, namun hal tersebut tidak akan berhasil tanpa adanya jalinan komunikasi yang berkualitas diantara keduanya. 
Jurnal Ilmu Komunikasi UHO : Jurnal Penelitian Kajian Ilmu Komunikasi dan Informasi.

Volume 6, No. 1, Januari 2021, hlm 1-18

Seperti yang dijelaskan oleh Wood dalam bukunya berjudul "Interpersonal Communication", setidaknya terdapat tiga dimenasi yang menjadi kunci sukses dalam menjalin suatu hubungan, yaitu: intimacy, passion dan commitment. Ketiga dimensi ini dinilai sebagai indikator yang tepat menurut Wood untuk mengukur berhasil atau tidaknya suatu hubungan.

Dalam temuan penelitian ini, dapat dipahami bahwa informan merasa tidak ada perbedaan yang mendasar antara menjalin hubungan secara online dan hubungan yang dijalin secara langsung. Kunci sukses dalam keberhasilan menjalin hubungan sangat bergantung pada ketertarikan dan minat satu sama lain. Jika seseorang tidak merasa cukup tertarik dan berminat untuk menjalani hubungan yang lebih serius, maka akan sulit baginya untuk mendapatkan hubungan yang berhasil. Oleh karena itu, berhasil dan tidaknya suatu hubungan sangat dipengaruhi oleh adanya minat diantara keduanya.

Temuan dari penelitian ini telah menunjukan bahwa informan memiliki niat untuk mencari pasangan hidup melalui aplikasi berbasis online. Walaupun niat tersebut tidak sepenuhnya diyakini akan berhasil, namun seiring berjalannya waktu, hal tersebut kini telah menjadi kenyataan. Hal ini telah menunjukan bahwa kerja keras yang dibarengi dengan niat dan minat yang tinggi tidak akan mengecewakan hasil.

Pada tahap intimacy, dapat dipahami bahwa informan merasa membutuhkan waktu yang cukup panjang untuk mengenal pasangan terlebih dahulu. Proses pengenalan dilakukan mulai dari percakapan yang terbilang sangat basic yakni menanyakan kebar, kegiatan yang sedang dijalani, hingga hobi. Namun seiring berjalannya waktu, konten percakapan tersebut seakan mengalir begitu saja hingga akhirnya terjalin hubungan yang cukup kuat dan berkembang menjadi sebuah rasa aman dan yakin satu sama lain dalam sebuah passion. Passion merupakan tahap kedua setelah terjalinnya intimacy dalam hubungan antar keduanya. Jika dalam intimacy, seseorang merasa sudah merasa dekat dan nyaman dengan pasangannya, maka pada tahap passion, seseorang mulai merasa yakin dan mantap untuk menguatkan hubungan dan membahagiakan satu sama lain.

Berdasarkan hasil wawancara, informan merasa mantap dan memiliki passion yang tinggi setelah melewati waktu selama lebih dari dua tahun. Hingga saat ini, informan telah menjalin hubungan dengan pasangannya selama 1 tahun 10 bulan. Waktu yang menurutnya cukup untuk dilanjutkan ke jenjang yang lebih serius, yakni pernikahan. Berdasarkan penjelasan tersebut, dapat disimpulkan bahwa adanya keseriusan dan komitmen yang kuat dalam suatu hubungan memerlukan waktu yang dinilai cukup bagi pengguna online dating. 
Jurnal Ilmu Komunikasi UHO : Jurnal Penelitian Kajian Ilmu Komunikasi dan Informasi.

Volume 6, No. 1, Januari 2021, hlm 1-18

Dalam hal ini, waktu yang dimaksud sangatlah bergantung pada kesiapan dan rencana yang hendak dijalani oleh pengguna online dating. Jika informan dalam penelitian ini merasa cukup dengan waktu yang dihabiskan selama 1 tahun 10 bulan, hal ini mungkin akan berbeda dengan pengguna online dating lainnya. Waktu yang dibutuhkan untuk menjalin hubungan yang lebih serius bergantung pada kesiapan pihak yang menjalani. Oleh karena itu, tidak ada batasan yang baku untuk mengukur berapa lama seseorang harus berkomitmen dengan hubungannya untuk melanjutkan ke jenjang yang lebih tinggi seperti pernikahan. 
Jurnal Ilmu Komunikasi UHO : Jurnal Penelitian Kajian Ilmu Komunikasi dan Informasi.

Volume 6, No. 1, Januari 2021, hlm 1-18

\section{DAFTAR PUSTAKA}

Adi, N.L. (2019). Pengelolaan Hubungan Antar Pribadi dari Pasangan yang Berkenalan Melalui Tinder. Interaksi: Jurnal Ilmu Komunikasi.

Anggraeni, Luthfi. Medcom.id (2020, 8 September). Mengenal Aplikasi Tinder yang Sedang Ramai Dibicarakan. https://www.medcom.id/teknologi/news-teknologi/GNl431VN-mengenalaplikasi-tinder-yang-sedang-ramai-

dibicarakan\#: :text=Sebagai\%20pengingat $\% 2 \mathrm{C} \% 20$ Tinder\%20didirikan\%20pada,perusahaan $\% 20$ induk\%20Tinder\%2C\%20Match\%20Group.

Armando, N.M., \& Faturochman, A.F. (2014). Penggunaan Tinder dan Pengembangan Hubungan dengan Match dalam Tinder (Studi Terhadap Mahasiswa/I Universitas Indonesia Pengguna Tinder).

Bilton, Nick. Nytimes.com. (2014, 29 Oktober). Tinder, the Fast-Growing Dating App, Taps an AgeOld Truth. https://www.nytimes.com/2014/10/30/fashion/tinder-the-fast-growing-dating-apptaps-an-age-old-truth.html.

Burns, Matt. Techcrunch.com. (2014, 11 Februari). Congratulations, Crunchies Winners! Kickstarter Wins Best Overall Startup. https://techcrunch.com/2014/02/10/congratulations-crunchieswinners-kickstarter-wins-best-overall-startup/

Castells, Manuel. (2009). Communication Power: Communication in the Digital Age. New York, US: Oxford University Press, Inc.

Cnnindonesia.com. (2019, 9 Agustus). 5,2 Juta Pengguna Rela Membayar Buat Main Tinder. https://www.cnnindonesia.com/teknologi/20190808141158-185-419539/52-juta-penggunarela-membayar-buat-main-tinder.

David, G., \& Cambre, C. (2016). Screened Intimacies: Tinder and the Swipe Logic. Social Media + Society.

Fridha, M., \& Octavianti, M. (2016). Konstruksi Makna Kencan di Situs Pencarian Jodoh Tinder (Studi Fenomenologi Pada Pria Pengguna Tinderdi Jakarta). Jurnal Nomosleca, Vol. 2, No. 2.

Griffin, Emory. (2011). A First Look at Communication Theory - Eight Edition. New York, US: McGraw-Hill Education.

Harness, Avissa. Kumparan.com. (2019, 5 JanuarI). Iseng Hingga One Night Stand, Alasan Mereka yang Lakukan Kencan Online.https://kumparan.com/kumparanstyle/iseng-hingga-one-nightstand-alasan-mereka-yang-lakukan-kencan-online-1546666167590610735.

Masaviru, M. (2016). Self-Disclosure: Theories and Model Review. Journal of Culture, Society and Development, Vol. 18.

Mulyadi, M. (2011). Penelitian Kuantitatif dan Kualitatif serta Pemikiran Dasar Menggabungkannya. Jurnal Studi Komunikasi dan Media, 16.

Neyt, B., Vandenbulcke, S., \& Baert, S. (2018). Education Level and Mating Success: Undercover on Tinder. Discussion Paper Series.

Panos, Dioysis. (2014). "I" on the Web: Social Penetration Theory Revisited. Mediterranean Journal of Social Sciences, Vol. 5, No. 19.

Pratomo, Yudha. Kompas.com. (2019, 16 Mei). APJII: Jumlah Pengguna Internet di Indonesia Tembus 171 Juta Jiwa. https://tekno.kompas.com/read/2019/05/16/03260037/apjii-jumlahpengguna-internet-di indonesia-tembus-171-juta-jiwa.

Prihastomo, Wahyu. Grid.id. (2019, 19 Desember). Netflix Jadi Aplikasi yang Paling Sering Dikunjungi 10 Tahun Ini. https://nextren.grid.id/read/011959000/netflix-jadi-aplikasi-yangpaling-sering-dikunjungi-10-tahun-ini?page=all.

Pu, W., Li, S., \& Tatcher, J (2016). Self-disclosure and SNS Platforms: The Impact of SNS Transparency and Culture. DIGIT 2016 Proceedings.

Rizki, A. (2018). Makna TinderSebagai Tempat Mendapatkan Teman Hidup. LONTAR: Jurnal Ilmu Komunikasi, Vol. 6, No. 1.

Rosa, A. O., Isabela, G.P.D.M., \& Jose, N.M. (2019). Looking for the right swipe: Gender Differences in Self-Presentation on Tinder Profiles. 
Jurnal Ilmu Komunikasi UHO : Jurnal Penelitian Kajian Ilmu Komunikasi dan Informasi.

Volume 6, No. 1, Januari 2021, hlm 1-18

Rusmana, Agus, dkk. (2019). Komunikasi Budaya dan Dokumentasi Kontemporer. Bandung, ID: Unpad Press.

Schutz, W.C. (1960). FIRO. A Three-Dimensional Theory of Interpersonal Behavior. International Journal of Group Psychoteraphy, Vol. 10

West, Richard., \& Turner, Lynn, H. (2018). Introducing Communication Theory: Analysis and Application $-6^{\text {th }}$ Edition. United States: McGraw-Hill Education.

Wpmultiverse.org. Tinder Statistics: Users, Data, Revenue, Gender \& More.https://wpmultiverse.org/statistics/tinder-statistics/ 